\title{
Effects of parasitism on diel vertical migration, phototaxis/geotaxis, and swimming speed of the bloom-forming dinoflagellate Akashiwo sanguinea
}

\author{
Myung Gil Park ${ }^{1, *}$, Sean K. Cooney ${ }^{1}$, Jae Seong Kim² ${ }^{2}$ D. Wayne Coats ${ }^{1}$ \\ ${ }^{1}$ Smithsonian Environmental Research Center, PO Box 28, Edgewater, Maryland 21037, USA \\ ${ }^{2}$ Department of Oceanography, College of Ocean Science and Technology, Kunsan National University, Kunsan 573-701, \\ Republic of Korea
}

\begin{abstract}
Eukaryotic parasites are believed to play important roles in bloom dynamics of red-tide dinoflagellates; however, little is known about their impact on host behavior. To address this issue, we examined the influence of the parasitic dinoflagellate Amoebophrya sp. on diel vertical migration (DVM), phototaxis/geotaxis, and swimming speed of the bloom-forming dinoflagellate Akashiwo sanguinea. Uninfected $A$. sanguinea exhibited strong DVM, yielding subsurface aggregations during the day and evenly dispersed populations at night. DVM of parasitized A. sanguinea was comparable to that of uninfected host for much of the infection cycle; however, subsurface accumulations of host cells were dramatically reduced or eliminated as parasites matured. The absence of DVM in the latter part of the infection cycle appeared to be associated with changes in phototaxic response and swimming speed of parasitized cells. While uninfected A. sanguinea exhibited strong positive phototaxis, hosts with late-stage infections exhibited strong negative phototaxis. By contrast, infected and uninfected A. sanguinea did not differ in geotaxis or sinking. Swimming speed of infected A. sanguinea decreased with parasite age, differing significantly from that of uninfected hosts $24 \mathrm{~h}$ after initiation of infections. A. sanguinea with late-stage infections exhibited a $37.3 \%$ lower swimming speed than uninfected hosts. Results indicate that parasitism by Amoebophrya sp. disrupts 'internal' factors that control DVM in dinoflagellates. Data also suggest that modification of host behavior by parasitism may contribute to vertical variations in phytoplankton species-composition and -abundance, particularly during epidemics when late-stage infections are prevalent.
\end{abstract}

KEY WORDS: Parasitism $\cdot$ Diel vertical migration - Taxis $\cdot$ Swimming speed $\cdot$ Behavior $\cdot$ Red tide $\cdot$ Akashiwo sanguinea

Resale or republication not permitted without written consent of the publisher

\section{INTRODUCTION}

Parasitic dinoflagellates have long been thought to play important roles in bloom dynamics of red-tide dinoflagellates (for recent review, see Elbrächter \& Schnepf 1998, Coats 1999). The genus Amoebophrya has received particular attention, as it is widely distrib-

*Present address: Red Tide Research Center, Kunsan National University, Kunsan 573-701, Republic of Korea. E-mail: myungpark@kunsan.ac.kr uted in coastal environments and has been reported from numerous host species (Cachon 1964, Taylor 1968, Elbrächter 1973, Nishitani et al. 1985, Cachon \& Cachon 1987, Fritz \& Nass 1992, Coats \& Bockstahler 1994, Coats et al. 1996, Maranda 2001). Prior studies have emphasized parasite morphology and life history (Coats \& Bockstahler 1994), prevalence and distribution of infections (Taylor 1968, Elbrächter 1973, Nishitani \& Chew 1984, Nishitani et al. 1984, 1985, Fritz \& Nass 1992, Coats \& Bockstahler 1994, Coats et al. 1996), and impact of parasitism on host populations (Coats \& Bockstahler 1994, Coats et al. 1996). Recently, 
Yih \& Coats (2000) examined the influence of host quality on the success of Amoebophrya sp. ex Akashiwo sanguinea and suggested that the parasite was well adapted to exploit dinoflagellate populations in nutrient enriched environments. Further, Park et al. (2002) found that photosynthetic performance and photophysiological properties of the bloom-forming dinoflagellates A. sanguinea and Gymnodinium instriatum were significantly altered following infection by parasites of the genus Amoebophrya. Despite growing interest in the ecological importance of parasites in red-tide dinoflagellates (Anderson 1997, Coats 1999, Norén et al. 1999, Erard-Le Denn et al. 2000), little is known about the influence of parasitism on host behavior.

This study was undertaken to test the hypothesis that parasitism by Amoebophrya sp. alters host behavior. To test the hypothesis, we compared diel vertical migration (DVM), phototaxis/geotaxis, and swimming speed of infected and uninfected cultures of Akashiwo sanguinea. The host-parasite system was isolated from Chesapeake Bay and is the same as that previously referred to as Amoebophrya ceratii ex Gymnodinium sanguineum (Coats et al. 1996), Amoebophrya sp. ex Gymnodinium sanguineum (Gunderson et al. 1999, Yih \& Coats 2000), and Amoebophrya sp. ex Akashiwo sanguinea (Park et al. 2002).

\section{MATERIALS AND METHODS}

Laboratory cultures. Chesapeake Bay isolates of Akashiwo sanguinea (formerly Gymnodinium sanguineum) and the parasitic dinoflagellate Amoebophrya sp. were maintained as stock cultures in $\mathrm{f} / 2$-Si medium (Guillard \& Ryther 1962) formulated using 15\% bay water plus soil extract ( $5 \% \mathrm{v} / \mathrm{v})$. Parasite cultures were propagated by sequentially transferring aliquots of infected $A$. sanguinea into uninfected host culture at 2 to $3 \mathrm{~d}$ intervals. Stock and experimental cultures were maintained at $20^{\circ} \mathrm{C}$ under a $14 \mathrm{~h}$ light:10 h dark cycle of cool-white fluorescent light at an irradiance of $175 \mu \mathrm{mol}$ photons $\mathrm{m}^{-2} \mathrm{~s}^{-1}$.

Diel vertical migration. Vertical migration of infected and uninfected Akashiwo sanguinea was examined using populations maintained in 21 plastic DVM columns measuring $46 \mathrm{~cm}$ in height and $8 \mathrm{~cm}$ in diameter. Each DVM column was wrapped with black tape and had sampling ports spaced at $4.5 \mathrm{~cm}$ intervals from $1 \mathrm{~cm}$ below the top (Port 1), to the bottom (Port 11) of the column. Ports were equipped with short tubes to permit collection of samples from the center of the column. A 12th refill port for addition of culture medium was positioned at the bottom of the column opposite sampling Port 11. Columns were maintained in a walk- in incubator at $20^{\circ} \mathrm{C}$ and illuminated from above using cool-white fluorescent light bulbs on a $14 \mathrm{~h}$ light:10 h dark cycle. Light intensity decreased exponentially from $80 \mu \mathrm{mol}$ photons $\mathrm{m}^{-2} \mathrm{~s}^{-1}$ at the uppermost sampling port to near zero at the bottom of the column.

Prior to initiation of the experiment, $800 \mathrm{ml}$ of Akashiwo sanguinea culture in exponential growth was brought to $8000 \mathrm{ml}$ by the addition of $15 \%$ filtered (Whatman GF/F) and sterilized Chesapeake Bay water. The 10-fold dilution of stock culture resulted in a host density of approximately 250 cells $\mathrm{ml}^{-1}$ and reduced growth medium to $\mathrm{f} / 20$ nutrient concentrations. The diluted culture was gently mixed, equally distributed to 4 DVM columns, and allowed to acclimate for ca. $5 \mathrm{~d}$. At circadian time (CT) 19 on the fifth day (CT is the time corresponding to the hour after the onset of the light period; during this study, the lights came on at CT 0 and went off at CT 14), $10 \mathrm{ml}$ aliquots were taken from sampling Ports 1, 3, 5, 7, 9, and 11 of each column, and $60 \mathrm{ml}$ of $15 \%$ sterile, filtered bay water was then added through the refill port. Samples were preserved with acid Lugol's fixative and used to determine A. sanguinea abundance following the methods of Park et al. (2002). At CT 20, 2 columns were inoculated with recently formed ( $\leq 6 \mathrm{~h}$ old) dinospores of Amoebophrya sp., while the other 2 columns served as uninfected controls. Recently formed dinospores were harvested and their abundance determined following established procedures (Park et al. 2002). Dinospores were injected uniformly through all 11 sampling ports of the 2 treatment columns to yield a dinospore:host ratio of 20:1, while equal volumes of dinospore filtrate (Whatman GF/F) were added through each port of the 2 control columns.

The vertical distribution of Akashiwo sanguinea in the 4 columns was determined $23 \mathrm{~h}$ (CT 19) after columns were inoculated and at approximately $5 \mathrm{~h}$ intervals thereafter (sampling times were CT 0, 4.5, 9, 14, and 19). At each sampling period, $10 \mathrm{ml}$ aliquots were taken from Ports 1, 3, 5, 7, 9, and 11 (depths of 1, $10,19,28,37$, and $46 \mathrm{~cm}$ ) of each column, and an equivalent volume $(60 \mathrm{ml})$ of $15 \%$ sterile, filtered bay water was replaced through the refilled port. Samples were preserved with modified Bouin's fixative (Coats \& Heinbokel 1982) and used to obtain host abundance and parasite prevalence following the methods of Park et al. (2002). Samples were stained with quantitative protargol staining (Montagnes \& Lynn 1993) and infections were classified as early and late following the criteria of Coats \& Bockstahler (1994).

Phototaxis, geotaxis, and sinking. To examine phototaxis, geotaxis, and sinking of infected and uninfected Akashiwo sanguinea, 4 DVM columns (2 treatments and 2 controls) were set up following the protocol described above. Sixty-two hours after the columns 
were inoculated (CT 9), a $400 \mathrm{ml}$ sample was taken through Port 3 of each column. Each sample was gently mixed and used to fill six $21 \mathrm{ml}$ glass test tubes that had been wrapped with black tape. Three tubes per column were sealed with clear plastic film for the phototaxis study, while the other 3 were covered with metal caps for the geotaxis experiment. The remaining sample from each column was preserved with $\mathrm{CaCO}_{3}$ buffered formalin ( $1 \%$ final concentration) and distributed to triplicate metal-capped tubes to determine sinking.

The 12 plastic-sealed 'phototaxis' tubes were placed horizontally on a shelf in a $20^{\circ} \mathrm{C}$ incubator, with the transparent end of the tubes facing cool-white fluorescent light bulbs. Irradiance at the transparent end of the tubes was equivalent to that available $10 \mathrm{~cm}$ below the surface (Port 3) of the DVM columns (i.e. $25 \mu \mathrm{mol}$ photons $\mathrm{m}^{-2} \mathrm{~s}^{-1}$ ). The 12 metal-capped 'geotaxis' tubes were placed vertically on an adjacent shelf, while the 12 metal-capped 'sinking' tubes were held in the laboratory at room temperature (ca. $20^{\circ} \mathrm{C}$ ). After a $2 \mathrm{~h}$ incubation, the phototaxis tubes were turned upright, and the fluid from the upper, middle, and lower thirds of each tube was transferred via syringes to 3 separate $20 \mathrm{ml}$ glass scintillation vials. The geotaxis tubes were incubated for only $30 \mathrm{~min}$ to minimize the effects of sinking but were sampled following the same protocol. Sinking tubes were likewise sampled after $30 \mathrm{~min}$. Samples for phototaxis and geotaxis experiments were preserved with Bouin's fixative for determination of host abundance, parasite prevalence, and parasite developmental stage as above. Akashiwo sanguinea densities were similarly obtained for formalin-fixed samples from the sinking experiment.

Swimming speed. Two $500 \mathrm{ml}$ flasks containing $250 \mathrm{ml}$ of Akashiwo sanguinea culture at ca. 1000 cells $\mathrm{ml}^{-1}$ were used to assess swimming speed of infected and uninfected host cells. One flask was inoculated at a dinospore:host ratio of 10:1, while the other served as an uninfected control. Flasks were maintained under growth conditions used for stock cultures and sampled at $8 \mathrm{~h}$ intervals after inoculation. At each sampling period, $10 \mathrm{ml}$ aliquots were taken from each flask and preserved with Bouin's fixative for determination of parasite prevalence and stage of infection. In addition, 10 subsamples $(1 \mathrm{ml}$ each) were transferred from each flask to separate multi-well plates. Multi-well plates were examined using a Lica/Wild stereoscope equipped with darkfield illumination and focused near the vertical center of the sample. Specimens swimming in the plane of focus of each $1 \mathrm{ml}$ subsample were videotaped over a $2 \mathrm{~min}$ period using a Sony DXC-760MD camera and JVC VHS Model HR-S4500U recorder capturing 30 frames $\mathrm{s}^{-1}$. Tapes were viewed on a Sony Trinitron PVM
1344Q monitor $(140 \times$ total magnification at viewing screen) using frame-by-frame playback. Specimens that maintained a linear path for $\geq 1 \mathrm{~s}$ were traced onto acetate overlays. Swimming speed was determined from the distance traversed in $1 \mathrm{~s}$, with care taken to analyze each specimen only once. This approach provided estimates of swimming speed for 10 specimens for each of 10 wells, with data obtained for 100 specimens for each flask at each sampling time.

Statistical analysis. For comparison of cell densities in replicate tubes of the taxis and sinking studies, data were $\log _{10}$ transformed to meet assumptions of normality and homogeneity of variance and then compared by 2-way ANOVA, with DVM column and replicate number being independent variables and cell density being the dependent variable. Percentage data for infected treatments and uninfected controls of the phototaxis, geotaxis, and sinking experiments were arcsine square-root transformed and compared by 2-way ANOVA, where tube position and presence or absence of parasites were independent variables and percentage of cells was the dependent variable. Data for swimming speeds of cells from infected treatments and uninfected controls were also compared by 2-way ANOVA, where elapsed time and presence or absence of parasites were independent variables and swimming speed was the dependent variable. Statistical comparisons were made using SigmaStat 3.0 (SPSS). Unless otherwise stated, data are reported as mean \pm standard error of the mean (SEM) for untransformed data from duplicate DVM columns.

\section{RESULTS}

\section{Diel vertical migration}

Mean abundance of Akashiwo sanguinea in treatment (infected) and control (uninfected) DVM columns was $170 \pm 10.9$ and $94 \pm 23.9$ cells ml$^{-1}$, respectively, at $T_{23}$ (where $T_{\mathrm{n}}$ is the time in hours after the start of the experiment). By the end of the experiment $\left(T_{71}\right), A$. sanguinea abundance had declined to $73 \pm 14.6$ and $49 \pm 7.4$ cells ml$^{-1}$ in the treatment and control groups, respectively, due to removal of cells during sampling and parasite induced mortality of hosts. Parasite prevalence increased quickly in infected treatments, with all samples having $100 \%$ infection levels from $T_{18}$ to the end of the experiment. The proportion of parasitized hosts exhibiting late-stage infections increased dramatically between the first and second light cycles (from $8 \pm 2.5 \%$ at $T_{42}$ to $69 \pm 2.5 \%$ at $T_{56.5}$ ) and reached $83 \pm 2.0 \%$ by the end of the second light period $\left(T_{66}\right)$.

Uninfected Akashiwo sanguinea had strong DVM over the 2 light:dark cycles, with subsurface $(10 \mathrm{~cm}$ 


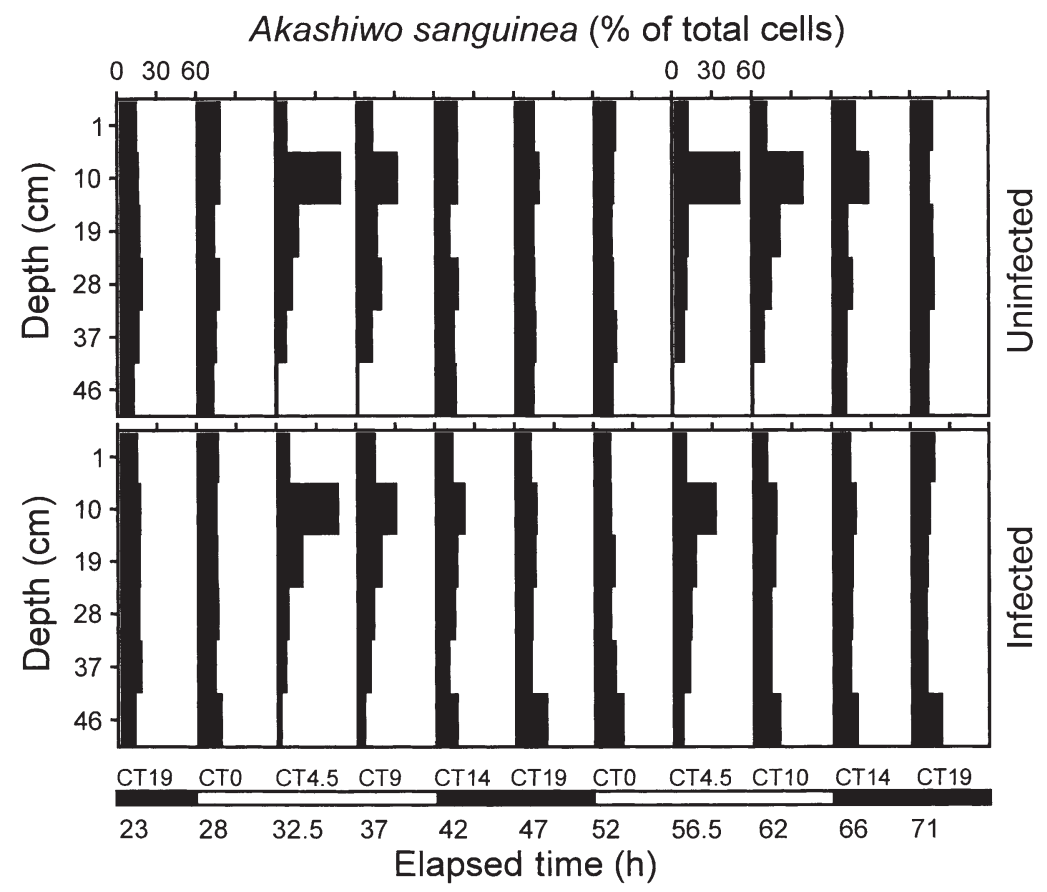

Fig. 1. Akashiwo sanguinea. Diel vertical migration of infected and uninfected A. sanguinea. Data are expressed as a percentage of total column cells using mean cell abundance of replicate columns. CT: circadian time, the time corresponding to the hour after the onset of the light period. During this study, light came on at CT 0 and off at CT 14. White and black areas of the bar under the $x$-axis represent the light and dark periods, respectively

surprisingly, therefore, cell densities of A. sanguinea in test tubes used for phototaxis, geotaxis, and sinking studies differed by treatment and in some cases within replicates. Two-way ANOVA conducted separately for the 3 experiments consistently showed significant differences in A. sanguinea density between uninfected and infected cultures ( $p<0.001)$. A. sanguinea density did not differ $(p>0.05)$ between replicates for the phototaxis and sinking studies, but did differ significantly $(\mathrm{p}<0.001)$ between replicates for the geotaxis experiment. Thus, A. sanguinea abundance at different positions in the phototaxis, geotaxis, and sinking tubes at the end of incubations could not be compared directly. Instead, cells present in each region were normalized to total number of cells to give the percentage of the A. sanguinea population at different levels in the tubes and then compared. The parasite prevalence in infected populations was $100 \pm 0.5 \%$, with most of the infections $(71 \pm 2.3 \%)$ being in late-stage development.

Akashiwo sanguinea from treatment and control columns showed opposite

depth) aggregations occurring during the day and populations being evenly dispersed at night (Fig. 1, upper panels). Peak subsurface accumulations occurred at CT 4.5 of both light periods and accounted for $49 \pm 5.0$ and $52 \pm 23.2 \%$ of the $A$. sanguinea population at $T_{32.5}$ and $T_{56.5}$, respectively. Infected $A$. sanguinea also exhibited strong DVM over the first light:dark cycle (Fig. 1, lower panels), with peak subsurface accumulations at CT 4.5 accounting for $47 \pm$ $4.9 \%$ of total cells present at $T_{32.5}$. Later in the infection cycle, however, parasitized cells appeared to loose their ability to migrate, as only a limited subsurface aggregation of cells (33 $\pm 9.3 \%$ of the population) was present at $T_{56.5}$ (CT 4.5), and no accumulations were evident thereafter.

\section{Taxis and sinking}

A separate set of treatment and control DVM columns was used to examine Akashiwo sanguinea phototaxis, geotaxis, and sinking. Infected and uninfected populations of $A$. sanguinea collected from the upper $10 \mathrm{~cm}$ of the DVM columns at $T_{62}$ averaged $130 \pm 19.8$ and $763 \pm 330.5$ cells $\mathrm{ml}^{-1}$, respectively. Not responses to light, as indicated by cell distributions in the phototaxis experiment (Fig. 2). Infected A. sanguinea exhibited negative phototaxis, with cell densities 2.8 times higher in the darkest third of the tube than in the third nearest the light. In contrast, uninfected A. san-

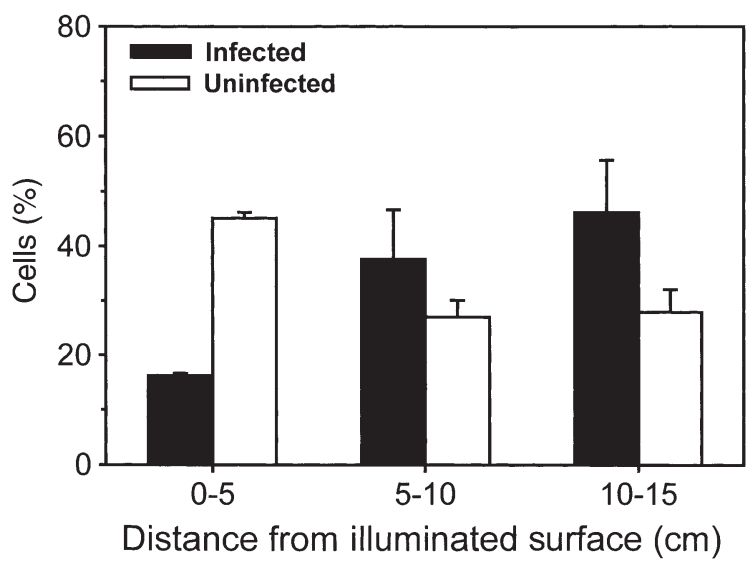

Fig. 2. Akashiwo sanguinea. Plot of phototaxis-precision strength in infected and uninfected $A$. sanguinea at $62 \mathrm{~h}$ after the parasite infection. Data are expressed as \% of total tube cells. Error bars represent SEM of duplicate tubes 


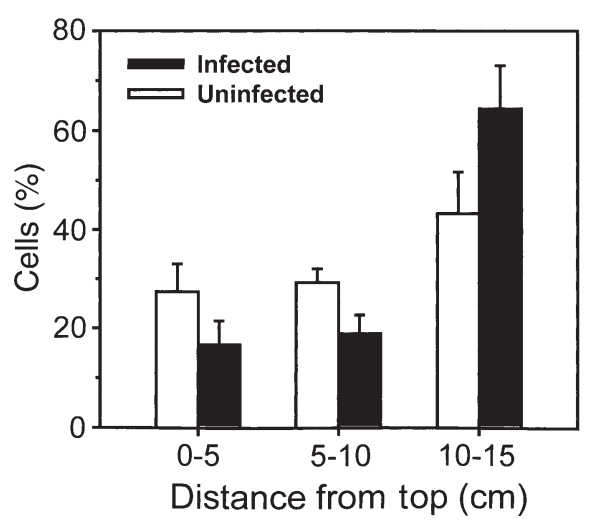

Fig. 3. Akashiwo sanguinea. Plot of geotaxis precision strength in infected and uninfected $A$. sanguinea at $62 \mathrm{~h}$ after the parasite infection. Data are expressed as \% of total tube cells. Error bars represent SEM of duplicate tubes

guinea showed positive phototaxis, with 1.6 times as many cells at the illuminated end of the tube as at the dark end. Two-way ANOVA showed no significant difference $(p>0.05)$ in mean percentage of cells by host types (infected versus uninfected) or by position in the phototaxis tube (illuminated third, middle third, darkest third) but did show a significant interaction between host type and position ( $p=0.013)$, indicating that the distribution of cells within the tubes depended on whether the hosts were infected. A posteriori pairwise comparison (Tukey's test) revealed a significant difference $(\mathrm{p}=0.009)$ in the percentage of infected versus uninfected $A$. sanguinea at the illuminated end of the phototaxis tubes. There was also a significant difference $(p=0.018)$ in the percentage of infected cells in the illuminated third versus darkest third of the tubes.

Both infected and uninfected Akashiwo sanguinea showed positive geotaxis (Fig. 3), with substantially more cells at the bottom of the tube $(64 \pm 9$ and $43 \pm 8 \%$, respectively) than at the top ( $17 \pm 5$ and $27 \pm 6 \%$, respectively). Two-way ANOVA indicated no significant difference $(p>0.05)$ in mean percentage of cells by host type, but did reveal a significant difference $(p=0.003)$ between regions of the geotaxis tube. There was no significant interaction between host type and position $(\mathrm{p}>0.05)$. A posteriori pairwise comparison indicated that the proportion of cells in the bottom third of the geotaxis tubes differed significantly from that in the top $(\mathrm{p}=0.005)$ and middle $(p=0.008)$ thirds. Infected and uninfected A. sanguinea also exhibited similar sinking patterns (Fig. 4), with 2-way ANOVA showing a significant difference $(p<0.001)$ in mean percentage of cells by position in the sinking tube, but not by host type $(p>0.05)$, and there was no significant interaction between position and host type $(p>0.05)$. A

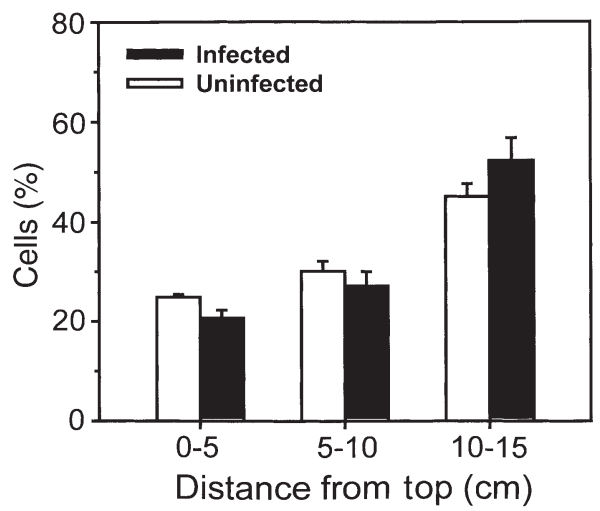

Fig. 4. Akashiwo sanguinea. Plot of sinking precision strength in infected and uninfected $A$. sanguinea at $62 \mathrm{~h}$ after the parasite infection. Data are expressed as \% of total tube cells. Error bars represent SEM of duplicate tubes

posteriori pairwise comparison indicated that there were significantly more cells in the bottom third of the sinking tubes than in the top or middle third $(\mathrm{p}<$ 0.001). Accumulation of infected and uninfected host cells in the bottom third of sinking tubes was 81 and $104 \%$, respectively, of that in geotaxis tube.

\section{Swimming speed}

The swimming speed of uninfected Akashiwo sanguinea remained stable during the experiment (Fig. 5), with values averaging $298 \pm 3.8 \mu \mathrm{m} \mathrm{s}^{-1}(\mathrm{n}=8)$ over the course of the experiment. In contrast, the swimming speed of parasitized $A$. sanguinea decreased during the experiment. Two-way ANOVA revealed signifi-

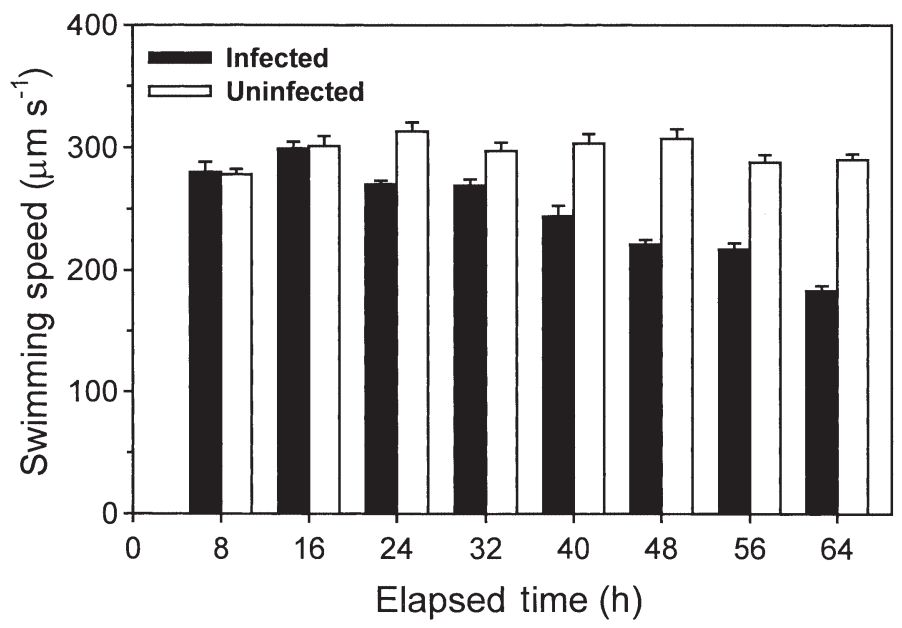

Fig. 5. Akashiwo sanguinea. Swimming speed of infected and uninfected $A$. sanguinea over the infection cycle of the parasite. Error bars represent SEM of duplicate tubes 
cant differences $(p<0.001)$ in swimming speed by host type (infected versus uninfected) and elapsed time after infection, with a significant $(\mathrm{p}<0.001)$ interaction effect between the two. A posteriori pairwise comparison indicated no significant difference $(p>0.05)$ in swimming speed between infected and uninfected cells at $T_{8}$ and $T_{16}$, but showed significant differences $(p<0.05)$ at all subsequent sampling times. Parasite prevalence at $T_{8}$ and $T_{16}$ was only 12 and $85 \%$, respectively. One day after inoculation $\left(T_{24}\right)$, parasite prevalence had increased to $97 \%$, with all parasites being in the early part of the infection cycle. Swimming speeds of infected $A$. sanguinea decreased steadily at subsequent sample times ( $T_{32}$ to $T_{64}$ ), with speeds $37 \%$ lower than those of uninfected cells at the end of the experiment. Parasite prevalence over that interval averaged $99.6 \pm 0.24 \%$ and most parasites (ca. $80 \%$ ) had reached the late phase of the infection cycle before sampling was terminated.

\section{DISCUSSION}

Uninfected cultures of Akashiwo sanguinea exhibited strong DVM similar to that reported for many dinoflagellates in previous field and laboratory studies (Cullen \& Horrigan 1981, Heaney \& Eppley 1981, Dortch \& Maske 1982, Kamykowski et al. 1998b). Parasitized A. sanguinea exhibited comparable DVM patterns throughout most of the infection cycle, but failed to form subsurface accumulations during late stages of parasite development. The loss of DVM during late infection appeared to reflect parasite-induced changes in host behavior, as uninfected hosts exhibited positive phototaxis during the light cycle, while hosts in late-stage infection showed negative phototaxis. Infected and uninfected populations of $A$. sanguinea appeared to move downward in the absence of light, supporting earlier reports that DVM encompasses a combination of phototaxis and geotaxis (Kamykowski et al. 1998b). Thus, negative phototaxis and positive geotaxis may work synergistically to promote downward migration of infected $A$. sanguinea. Sinking was also pronounced during the time frame of our geotaxis experiments (30 min), raising the possibility that passive forces contributed to downward movement of cells. Sinking, however, probably had little influence on results of geotaxis experiments for uninfected A. sanguinea, as cells swam at relatively constant rates throughout the light:dark cycle $\left(298 \pm 3.8 \mu \mathrm{m} \mathrm{s}^{-1}\right)$. In contrast, swimming speeds of infected hosts decreased markedly (by as much as $37 \%$ relative to uninfected $A$. sanguineum), which may have inhibited the ability of parasitized cells to migrate toward the surface.
Coats \& Bockstahler (1994) reported sharp vertical separation of infected and uninfected Akashiwo sanguinea in Chesapeake Bay, and noted a high prevalence of late-stage infections near the pycnocline, several meters beneath dense, but lightly infected, surface populations. They argued that vertical uncoupling of host and parasite populations reflected either rapid sinking of infected A. sanguinea or failure of parasitized hosts to migrate upward during the day (i.e. loss of phototaxis). While our results do not exclude sinking as having an influence on distributions of parasitized hosts in the field, they strongly favor the interpretation that the concentration of Amoebophrya sp. at depth reflects a loss of phototaxis and DVM. Our data also indicate that active downward swimming of infected cells (geotaxis) contributes to the vertical distribution of parasite populations in the field. Nonetheless, other factors may also contribute to vertical heterogeneity of infected dinoflagellate hosts. For example, Johansson \& Coats (2002) recently showed that grazing by ciliates can limit the success of dinospores from Amoebophrya sp., with differential grazing pressure potentially influencing parasite prevalence.

The loss of phototaxis during late infection suggests that Amoebophrya sp. blinds the photoreceptor and/or eyespot of Akashiwo sanguinea, thereby preventing infected cells from sensing light and orienting themselves toward the stimulus. Interestingly, Amoebophrya sp. ex A. sanguinea always develops inside the nucleus of its host (Coats \& Bockstahler 1994). While migration of dinospores through the host cytoplasm is required prior to invading the nucleus, parasites may not come into direct contact with host cytoplasmic structures once infections are established. Thus, blinding of the host's photoreceptor and/or eyespot may not involve direct interactions like ingestion or digestion of structural elements. Rather, indirect interference seems more likely and may involve disruption of physiological or biochemical states in the signal transduction chain from the photoreceptor to flagella (Kreimer 1994). Alternatively, growth of the parasite may alter phototaxis by shading the host's photoreceptor. This seems plausible, as growth of Amoebophrya sp. ex A. sanguinea causes enlargement of the host's episome and may partially block light from reaching the photoreceptor, which in many dinoflagellates is located on the ventral surface, just under the sulcus or beneath the base of the longitudinal flagellum near the junction of the sulcus and cingulum (Levandowsky \& Kaneta 1987, Kreimer 1994).

While the swimming speed of uninfected Akashiwo sanguinea was more or less stable during the experiment, the swimming speed of parasitized A. sanguinea decreased steadily after the early stage of the infection cycle. Forward et al. (1986) reported that the swim- 
ming speed of A. sanguinea (Gymnodinium splendens) varied up to 2-fold in response to temperature changes between 13 and $25^{\circ} \mathrm{C}$ and showed that the effect of temperature on swimming speed was especially dramatic between 19 and $21^{\circ} \mathrm{C}$. Since our cultures were grown at $20^{\circ} \mathrm{C}$, subtle changes in temperature resulting during microscopic examination or video recording could have influenced our estimates of swimming speed. Since infected and uninfected treatments were handled in the same way, it seems unlikely that any change in swimming speed due to change in temperature would have biased experimental outcomes; however, differential effects of temperature on the swimming speed of uninfected and infected $A$. sanguinea cannot be ruled out and need to be addressed in future studies. There are at least 3 other possible explanations for the reduced speed in infected cells: (1) energy diverted to growth of the parasite; (2) mechanical effects caused by the parasite inside the host cell; or (3) changes in host cell size, drag, or mass. Resolution of the possibilities will also require additional study.

In field populations of dinoflagellates, DVM patterns can be influenced by a variety of external environmental and internal cellular factors, including light intensity (Eppley et al. 1968, Blasco 1978, Heaney \& Eppley 1981, Passow 1991), temperature (Kamykowski 1981), salinity (Kamykowski 1981, Tyler \& Seliger 1981), oxygen (Harris et al. 1979), nutrient concentrations (Cullen \& Horrigan 1981, Heaney \& Eppley 1981, MacIntyre et al. 1997), and cellular biochemical pools (Cullen 1985, Cullen et al. 1985, Kamykowski et al. 1998a). Our result suggests that parasitism is yet another internal factor that can alter DVM of dinoflagellates. Furthermore, results from this study suggest that modification of host behavior by parasitism may contribute to vertical variations in phytoplankton species composition and abundance, particularly during epidemics when late-stage infections are prevalent. The energy budgets of the host cell may also be expected to vary over the infection cycle. For example, infected host cells might invest more energy than uninfected cells in maintaining an appropriate vertical position within the water column. In addition, parasitism can have significant impacts on host physiology (Park et al. 2002) and may alter the photosynthetic potential of different cell types in the water column.

Acknowledgements. This research was supported by NSF award OCE-9730695 to D.W.C. We thank 2 anonymous reviewers for their helpful comments on the manuscript.

\section{LITERATURE CITED}

Anderson DM (1997) Turning back the harmful red tide. Nature 388:513-514
Blasco D (1978) Observations on the diel migration of marine dinoflagellates off the Baja California coast. Mar Biol 46: $41-47$

Cachon J (1964) Contribution à l'étude des péridiniens parasites. Cytologie, cycles évolutifs. Ann Sci Nat Zool 6:1-158

Cachon J, Cachon M (1987) Parasitic dinoflagellates. In: Taylor FJR (ed) The biology of dinoflagellates. Blackwell Scientific Publications, Oxford, p 571-610

Coats DW (1999) Parasitic life styles of marine dinoflagellates. J Eukaryot Microbiol 46:402-409

Coats DW, Bockstahler KR (1994) Occurrence of the parasitic dinoflagellate Amoebophrya ceratii in Chesapeake Bay populations of Gymnodinium sanguineum. J Eukaryot Microbiol 41:586-593

Coats DW, Heinbokel JF (1982) A study of reproduction and other life cycle phenomena in planktonic protists using an acridine orange fluorescence technique. Mar Biol 67: 71-79

Coats DW, Adam EJ, Gallegos CL, Hedrick S (1996) Parasitism of photosynthetic dinoflagellates in a shallow subestuary of Chesapeake Bay, USA. Aquat Microb Ecol $11: 1-9$

Cullen JJ (1985) Diel vertical migration by dinoflagellates: roles of carbohydrate metabolism and behavioral flexibility. In: Rankin MA (ed) Migration: mechanisms and adaptive significance. Cont Mar Sci 27:135-152

Cullen JJ, Horrigan SG (1981) Effects of nitrate on the diurnal vertical migration, carbon to nitrogen ratio, and the photosynthetic capacity of the dinoflagellate, Gymnodinium splendens. Mar Biol 62:81-89

Cullen JJ, Zhu M, Davis RF, Pierson DC (1985) Vertical migration, carbohydrate synthesis and nocturnal uptake during growth of Heterocapsa niei in a laboratory column. In: Anderson DM, White AW, Baden DG (eds) Toxic dinoflagellates. Elsevier, New York, p 189-194

Dortch Q, Maske H (1982) Dark uptake of nitrate and nitrate reductase activity of a red-tide population off Peru. Mar Ecol Prog Ser 9:299-303

Elbrächter M (1973) Population dynamics of Ceratium in coastal waters of the Kiel Bay. Oikos 15(Suppl):43-48

Elbrächter M, Schnepf E (1998) Parasites of harmful algae. In: Anderson DM, Cembella AD, Hallegraeff GM (eds) Physiological ecology of harmful algal blooms. SpringerVerlag, Berlin, p 351-369

Eppley RW, Holm-Hansen O, Strickland JDH (1968) Some observations on the vertical migration of dinoflagellates. J Phycol 4:333-340

Erard-Le Denn E, Chrétiennot-Dinet JM, Probert I (2000) First report of parasitism on the toxic dinoflagellates Alexandrium minutum Halim. Estuar Coast Shelf Sci 50:109-113

Forward RB Jr, Mendiola BR, Barber RT (1986) Effects of temperature on swimming speed of the dinoflagellate Gymnodinium splendens. Fish Bull 84:460-463

Fritz L, Nass M (1992) Development of the parasitic dinoflagellate Amoebophrya ceratii within host dinoflagellate species. J Phycol 28:312-320

Guillard RRL, Ryther JH (1962) Studies on marine planktonic diatoms. I. Cyclotella nana Hustedt and Detonula confervacea (Cleve) Gran. Can J Microbiol 8:229-239

Gunderson JH, Goss SH, Coats DW (1999) The phylogenetic position of Amoebophrya sp. from Gymnodinium sanguineum. J Eukaryot Microbiol 46:194-197

Harris GP, Heaney SI, Talling JF (1979) Physiological and environmental constraints in the ecology of the planktonic dinoflagellate Ceratium hirundinella. Freshw Biol 9: 413-428

Heaney SI, Eppley RW (1981) Light, temperature and nitro- 
gen as interacting factors affecting diel vertical migration of dinoflagellates in culture. J Plankton Res 3:331-334

Johansson M, Coats DW (2002) Ciliate grazing on the parasite Amoebophrya sp. decreases infection of the red-tide dinoflagellate Akashiwo sanguinea. Aquat Microb Ecol 28:69-78

Kamykowski D (1981) Laboratory experiments on the diurnal vertical migration of marine dinoflagellates through temperature gradients. Mar Biol 62:57-64

Kamykowski D, Milligan EJ, Reed RE (1998a) Biochemical relationships with the orientation of the autotrophic dinoflagellate Gymnodinium breve under nutrient replete conditions. Mar Ecol Prog Ser 167:105-117

Kamykowski D, Milligan EJ, Reed RE (1998b) Relationships between geotaxis/phototaxis and diel vertical migration in autotrophic dinoflagellates. J Plankton Res 20:1781-1796

Kreimer G (1994) Cell biology of phototaxis in flagellate algae. Int Rev Cytol 148:229-310

Levandowsky M, Kaneta P (1987) Behavior in dinoflagellates. In: Taylor FJR (ed) The biology of dinoflagellates. Blackwell Scientific Publications, Oxford, p 360-397

MacIntyre JG, Cullen JJ, Cembella AD (1997) Vertical migration, nutrition and toxicity in the dinoflagellate Alexandrium tamarense. Mar Ecol Prog Ser 148:201-216

Maranda L (2001) Infection of Prorocentrum minimum (Dinophyceae) by the parasite Amoebophrya sp. (Dinoflagellea). J Phycol 37:245-248

Montagnes DJS, Lynn DH (1993) A quantitative protargol stain (QPS) for ciliates and other protists. In: Kemp PF, Sherr BF, Sherr EB, Cole JJ (eds) Handbook of methods in aquatic microbial ecology. Lewis Publishers, Boca Raton, p 229-240

Nishitani L, Chew KK (1984) Recent developments in

Editorial responsibility: William Li,

Dartmouth, Nova Scotia, Canada paralytic shellfish poisoning research. Aquaculture 39: 317-329

Nishitani L, Hood R, Wakeman J, Chew KK (1984) Potential importance of an endoparasite of Gonyaulax in paralytic shellfish poisoning outbreaks. In: Ragelis EP (ed) Seafood toxins. ACS Symp Ser 262:139-149

Nishitani L, Erickson G, Chew KK (1985) Role of the parasitic dinoflagellate Amoebophrya ceratii in control of Gonyaulax catenella populations. In: Anderson DM, White AW, Baden DG (eds) Toxic dinoflagellates. Elsevier, New York, p 225-230

Norén F, Moestrup Ø, Rehnstam-Holm AS (1999) Parvilucifera infectans Norén et Moestrup gen. et sp. nov. (Perkinsozoa phylum nov.): a parasitic flagellate capable of killing toxic microalgae. Eur J Protistol 35:233-254

Park MG, Cooney SK, Yih W, Coats DW (2002) Effects of two strains of the parasitic dinoflagellate Amoebophrya on growth, photosynthesis, light absorption, and quantum yield of bloom-forming dinoflagellates. Mar Ecol Prog Ser 227:281-292

Passow U (1991) Vertical migration of Gonyaulax catenata and Mesodinium rubrum. Mar Biol 110:455-463

Taylor FJR (1968) Parasitism of the toxin-producing dinoflagellate Gonyaulax catenella by the endoparasitic dinoflagellate Amoebophrya ceratii. J Fish Res Board Can 25: 2241-2245

Tyler MA, Seliger HH (1981) Selection for a red tide organism: physiological responses to the physical environment. Limnol Oceanogr 26:310-324

Yih W, Coats DW (2000) Infection of Gymnodinium sanguineum by the dinoflagellate Amoebophrya sp.: effect of nutrient environment on parasite generation time, reproduction, and infectivity. J Eukaryot Microbiol 47:504-510

Submitted: November 23, 2001; Accepted: May 10, 2002 Proofs received from author(s): July 31, 2002 